\title{
Urban Sustainable Development Capacity Evaluation Model Research and Application Based on entropy and distance functions
}

\author{
Bingfeng Ruan ${ }^{1, \mathrm{a}}$ Huarui $\mathrm{Wu}^{1,2, \mathrm{~b}}$ \\ ${ }^{1}$ Beijing Research Center of Intelligent Equipment for Agriculture, \\ Beijing 100097,China \\ ${ }^{2}$ National Research Center of Intelligent Equipment for Agriculture, \\ Beijing 100097, China, \\ aemail:: liuxq@nercita.org.cn , bemail:wuhr@nercita.org.cn
}

\begin{abstract}
Sustainable development is an important issue in the world care, research and exploration on various aspects of sustainable development has also been concerned about the community, the issue of sustainable urban development is one of them. This will combine the connotation of sustainable urban development, to model for urban sustainable development capacity assessment model by studying entropy and distance function two mathematical theory, and to index data for the experimental area Shaoxing application examples, combined with the establishment of the evaluation model to evaluate their capacity for sustainable development, science and government departments to help understand the local level of sustainable urban development, provide the basis for scientific decision-making for sustainable urban development.
\end{abstract}

Keywords:Sustainable Urban Development; Entropy; Distance Function; Assessment Model

\section{Introduction}

Sustainable urban development is a social, ecological (environment), the economy maintained a high degree of harmony in the process. In order to fully reflect the status of this complex system, comprehensive evaluation of sustainable development need to adopt multi-index comprehensive evaluation method, that is more than describe the area being evaluated social, ecological (environment) and economic dimension different set of statistical indicators, transforming become dimensionless relative evaluation values, and the combination of these evaluation values to arrive at an assessment of the region on an overall assessment of sustainable development, the core of the problem is the evaluation methods[1]. In this paper, by studying entropy and two mathematical theory to model the distance function model for urban sustainable development capacity assessment model, and to index data for the experimental area Shaoxing application examples, combined with the establishment of its 
evaluation model for sustainable develop the ability to evaluate the capacity of sustainable development for the city's comprehensive evaluation and analysis to provide a strong scientific basis.

\section{Research Methods}

\subsection{Entropy}

(1)Comprehensive evaluation of information entropy and weighting function

Suppose you need to evaluate the development of Shaoxing $\mathrm{m}$ years, the evaluation index system includes $\mathrm{n}$ indicators. This is a sample composed by $\mathrm{m}$ by $\mathrm{n}$ indices do comprehensive evaluation of the problem, this mathematical model is as follows:

On the field is:

$$
\mathrm{U}=\left\{\mathrm{u}_{1}, \mathrm{u}_{2}, \ldots \mathrm{u}_{\mathrm{i}} \ldots \mathrm{u}_{\mathrm{m}}\right\} \quad(\mathrm{i}=1,2, \cdots, \mathrm{m})
$$

Each sample (evaluated) $u_{\mathrm{i}}$ with $\mathrm{n}$ indexes the data Characterization:

$\mathrm{u}_{\mathrm{i}}=\left\{\mathrm{X}_{\mathrm{i} 1}, \mathrm{X}_{\mathrm{i} 2}, \ldots \mathrm{X}_{\mathrm{ij}} \ldots \mathrm{X}_{\mathrm{in}}\right\} \quad(\mathrm{j}=1,2, \ldots \mathrm{n})$

Obtain initial data matrix evaluation system $: X=\left\{X_{i j}\right\}_{m \times n}$

The matrix is normalized initial matrix: $\mathrm{Y}=\left\{\mathrm{y}_{\mathrm{ij}}\right\}_{\mathrm{m} \times \mathrm{n}}$

Entropy item $\mathrm{j}$ index values are: $\mathrm{e}_{\mathrm{j}}=-\mathrm{k} \sum_{\mathrm{i}=1}^{\mathrm{m}} \mathrm{y}_{\mathrm{ij}} \ln \mathrm{y}_{\mathrm{ij}}$

$\mathrm{M}$ the number of samples where the constant $\mathrm{k}$ related to the system: $\mathrm{k}=\frac{1}{\mathrm{lnm}}$

The difference between information and a utility value of an index depends on the index of information entropy $e_{j}$ and $1: d_{j}=1-e_{j}$

Estimates using entropy weight of each index, its essence is to use the index information to calculate the value of the coefficient, the value of the coefficient, the greater the importance of the evaluation, and finally get the item $j$ index weights as follows: $w_{j}=\frac{d_{j}}{\sum_{j=1}^{n} d_{j}}$

(2)Evaluation of multi-evaluation system

For evaluation system multi-layer structure, according to the entropy can be additive, you can use the utility value of the underlying index information structure, determined by the ratio of the upper structure corresponding to the weight $\mathrm{w}_{\mathrm{j}}$ value. Indicators for each type of utility value of the underlying structure of the summation, get all kinds of indicators of utility value and, denoted $D_{k}(k=1,2, \ldots k)$, and then get the sum of all indicators utility value $\mathrm{D}=\sum_{\mathrm{k}=1}^{2} \mathrm{D}_{\mathrm{k}}$

The corresponding right weight class: $\mathrm{W}_{\mathrm{k}}=\frac{\mathrm{D}_{\mathrm{k}}}{\mathrm{D}}$

\subsection{Distance Function}

Distance function model is a method of comprehensive evaluation model, the basic idea is: conducting a comparative evaluation of multi-subject similarity between indicators, the evaluation of the original data set mapping coordinates of points on the current situation in n-dimensional space, and target indicator, or the area of the ideal value of the optimal target value corresponds to the coordinates 
of the point in space, the core is a comprehensive evaluation model calculate the distance value Status indicators and a target point, according to the size and distance of the comprehensive judgment evaluation of the relative levels of each object differences.

For the i-th index, the actual data set its target for $X_{i}\left(x_{i 1}, x_{i 2}, \ldots x_{i j}\right), i=$ $1,2,3, \ldots \mathrm{m}$, where $\mathrm{m}$ is the total number of index system indicators, $\mathrm{j}$ represent individual indicators included the number of data.

Set $\left(\mathrm{x}_{\mathrm{i} 1}, \mathrm{x}_{\mathrm{i} 2}, \ldots \mathrm{x}_{\mathrm{ij}}\right)$ corresponds to the status quo point coordinates $\mathrm{j}$-dimensional space for $\mathrm{x}_{\mathrm{i}}\left(\mathrm{x}_{\mathrm{i} 1}, \mathrm{x}_{\mathrm{i} 2}, \ldots \mathrm{x}_{\mathrm{ij}}\right)$, namely the status quo coordinate space, and set the corresponding experimental zone Shaoxing urban sustainable development capacity in space target point coordinatesy $\mathrm{y}_{\mathrm{i}}\left(\mathrm{y}_{\mathrm{i} 1}, \mathrm{y}_{\mathrm{i} 2}, \ldots \mathrm{y}_{\mathrm{ij}}\right)$.

Calculate the distance value, that is seeking the status quo point in multidimensional space $\mathrm{x}_{\mathrm{i}}\left(\mathrm{x}_{\mathrm{i} 1}, \mathrm{x}_{\mathrm{i} 2}, \ldots \mathrm{x}_{\mathrm{ij}}\right)$ and the target point $\mathrm{y}_{\mathrm{i}}\left(\mathrm{y}_{\mathrm{i} 1}, \mathrm{y}_{\mathrm{i} 2}, \ldots \mathrm{y}_{\mathrm{ij}}\right)$ $\operatorname{ofd}_{\mathrm{i}}\left(\mathrm{x}_{\mathrm{i}}, \mathrm{y}_{\mathrm{i}}\right)$ distance between two coordinate points $\left(\mathrm{x}_{\mathrm{i}}, \mathrm{y}_{\mathrm{i}}\right)$.

Euclidean distance formula :

$\mathrm{d}_{\mathrm{i}}\left(\mathrm{x}_{\mathrm{i}}, \mathrm{y}_{\mathrm{i}}\right)=\sqrt[2]{\sum_{\mathrm{i}=1}^{\mathrm{n}}\left(\omega_{\mathrm{i}} \mathrm{E}_{\mathrm{i}}-\omega_{\mathrm{i}}\right)^{2}}$

Among them, $\omega_{\mathrm{i}}$ as an indicator $\mathrm{x}_{\mathrm{i}}$ weights and $\sum_{\mathrm{i}=1}^{\mathrm{n}} \omega_{\mathrm{i}}=1, \mathrm{E}_{\mathrm{i}}$ index normalized data, when $\mathrm{x}_{\mathrm{ij}}$ to play role in promoting sustainable development, that is a positive indicator, $E_{i}=x_{i j} / y_{i j}$, contrary to reverse indicator, $E_{i}=$ $\mathrm{y}_{\mathrm{ij}} / \mathrm{x}_{\mathrm{ij}}$.

\section{Application Examples}

\subsection{Raw data: Shaoxing indicators and data}

In this paper, Shaoxing City, Zhejiang Provience actual indicators and data, in accordance with the principles of data validity and integrity, from Shaoxing City, eco-development, social development perspectives focus on selected index system of sustainable development on two levels, including two-level indicators, thirteen two indexes. Shaoxing covers both social and ecological, indicators and data table below for Shaoxing experimental area.An index system diagram Shaoxing.

According to data provided by Shaoxing City (see Table 1), using the method of calculating the entropy of each index weights.

Table 1 Indicators data Shaoxing 2007--2012

\begin{tabular}{|l|l|l|l|l|l|l|l|}
\hline & $\begin{array}{r}\text { Index } \\
\text { name and unit }\end{array}$ & 2007 & 2008 & 2009 & 2010 & 2011 & 2012 \\
\hline & $\begin{array}{l}\text { Per capita } \\
\text { parkland area } \\
\text { (square } \\
\text { Ecology }\end{array}$ & 8.89 & 9.07 & 12.15 & 12.26 & 12.6 & 12.54 \\
\hline
\end{tabular}




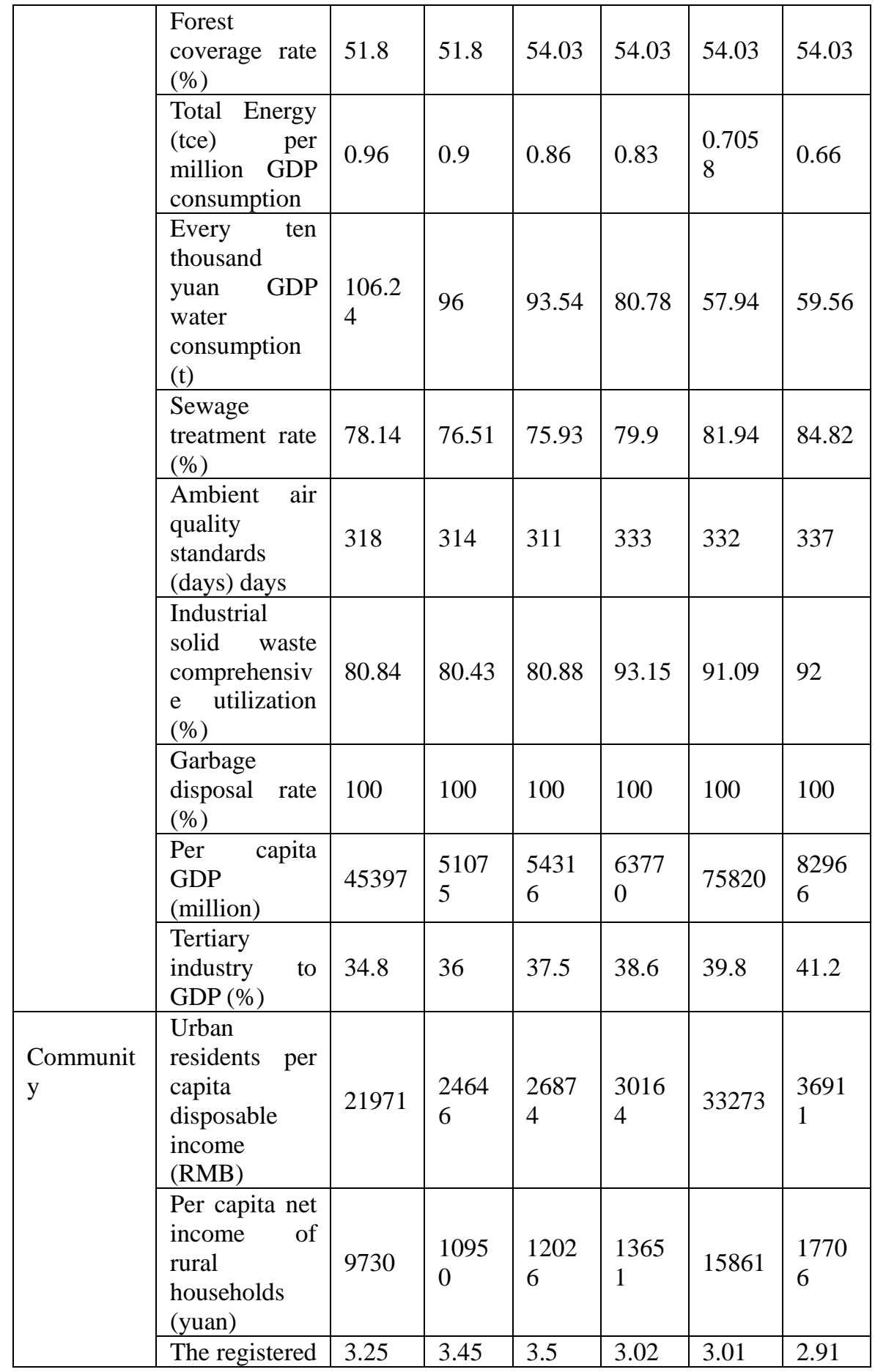




\begin{tabular}{|l|l|l|l|l|l|l|l|}
\hline & $\begin{array}{l}\text { urban } \\
\text { unemploymen } \\
\text { t rate (\%) }\end{array}$ & & & & & & \\
\hline
\end{tabular}

\subsection{Calculation of weight right}

According to 2007-2012 data Shaoxing indicators provided by entropy method to calculate the weight of each indicator.

The remaining index weights calculated by reference to the formula weight, and finally determine the weight of each index weight, the results see Table 2 .

Table 2 weight values for each index

\begin{tabular}{|c|c|c|c|}
\hline First index & Second index & $\begin{array}{l}\text { Second index } \\
\text { weight }\end{array}$ & $\begin{array}{c}\text { First index } \\
\text { weight value }\end{array}$ \\
\hline \multirow{10}{*}{ Ecology } & $\begin{array}{l}\text { Eco-park per capita green } \\
\text { area }\end{array}$ & 0.0958 & \multirow{10}{*}{0.7772} \\
\hline & Forest coverage & 0.1095 & \\
\hline & $\begin{array}{l}\text { Total energy consumption } \\
\text { per yuan GDP }\end{array}$ & 0.0683 & \\
\hline & $\begin{array}{l}\text { Every ten thousand yuan } \\
\text { GDP water consumption }\end{array}$ & 0.0819 & \\
\hline & Sewage treatment rate & 0.0758 & \\
\hline & $\begin{array}{l}\text { Ambient air quality standard } \\
\text { number }\end{array}$ & 0.0858 & \\
\hline & $\begin{array}{l}\text { Industrial solid waste } \\
\text { comprehensive utilization }\end{array}$ & 0.1187 & \\
\hline & Garbage disposal rate & $4.983 e^{-16}$ & \\
\hline & Per capita GDP & 0.0758 & \\
\hline & Tertiary industry GDP ratio & 0.0658 & \\
\hline \multirow[t]{3}{*}{ Community } & $\begin{array}{l}\text { Social urban residents per } \\
\text { capita disposable income }\end{array}$ & 0.0673 & \multirow[t]{3}{*}{0.2228} \\
\hline & $\begin{array}{l}\text { Per capita net income of rural } \\
\text { households }\end{array}$ & 0.0711 & \\
\hline & $\begin{array}{lrl}\text { The registered } & \text { urban } \\
\text { unemployment rate } & \end{array}$ & 0.0844 & \\
\hline
\end{tabular}

\subsection{Comprehensive distance calculation}

Application distance function method to establish sustainable urban development assessment model for calculating the weight of the right to primary and secondary indicators and standardizing the data, based on experimental zone of Shaoxing, City 2013 study of urban sustainable development capacity, establish experimental zone of Shaoxing City Sustainable Development Capacity index system, specifically see table 3 . 
Table 3 An index two indicators Unit 2013 reference standard and index weight basis

\begin{tabular}{|c|c|c|c|c|c|c|}
\hline $\begin{array}{l}\text { First } \\
\text { Index }\end{array}$ & $\begin{array}{l}\text { Second } \\
\text { index }\end{array}$ & Unit & 2013 & $\begin{array}{l}\text { referen } \\
\text { ce } \\
\text { standar } \\
\text { d and } \\
\text { index }\end{array}$ & $\begin{array}{l}\text { weig } \\
\text { ht basis }\end{array}$ & $\begin{array}{l}\text { Standardiz } \\
\text { ed data }\end{array}$ \\
\hline \multirow[t]{9}{*}{ Ecology } & $\begin{array}{l}\text { green area } \\
\text { per capita } \\
\text { ecological } \\
\text { park }\end{array}$ & $\begin{array}{l}\text { Square } \\
\text { meter }\end{array}$ & $\begin{array}{c}12.6 \\
2\end{array}$ & $\begin{array}{l}>11 \\
\text { national } \\
\text { standar } \\
\text { d }\end{array}$ & 0.0958 & 1.1473 \\
\hline & $\begin{array}{l}\text { forest } \\
\text { coverage } \\
\text { rate }\end{array}$ & $\%$ & $\begin{array}{c}54.0 \\
3\end{array}$ & $\begin{array}{l}>15 \\
\text { national } \\
\text { standar } \\
\text { d }\end{array}$ & 0.1095 & 3.6020 \\
\hline & $\begin{array}{l}\text { total energy } \\
\text { consumption } \\
\text { per ten } \\
\text { thousand } \\
\text { yuanGDP }\end{array}$ & ton & 0.63 & $\begin{array}{l}<0.9 \\
\text { national } \\
\text { standar } \\
\text { d }\end{array}$ & 0.0683 & 1.4286 \\
\hline & $\begin{array}{l}\text { water } \\
\text { consumption } \\
\text { Per ton ten } \\
\text { thousand } \\
\text { yuan GDP }\end{array}$ & ton & $\begin{array}{c}47.2 \\
3\end{array}$ & $\begin{array}{l}<150 \\
\text { national } \\
\text { standar } \\
\text { d }\end{array}$ & 0.0819 & 3.1759 \\
\hline & $\begin{array}{l}\text { Sewage } \\
\text { treatment } \\
\text { rate }\end{array}$ & $\%$ & $\begin{array}{c}86.1 \\
9\end{array}$ & $\begin{array}{l}>85 \\
\text { national } \\
\text { standar } \\
\text { d }\end{array}$ & 0.0758 & 1.014 \\
\hline & $\begin{array}{l}\text { Ambient air } \\
\text { quality } \\
\text { standard } \\
\text { number of } \\
\text { days }\end{array}$ & day & 312 & $\begin{array}{l}>280 \\
\text { national } \\
\text { standar } \\
\text { d }\end{array}$ & 0.0858 & 1.1143 \\
\hline & $\begin{array}{l}\text { Industrial } \\
\text { solid waste } \\
\text { comprehensi } \\
\text { ve utilization }\end{array}$ & $\%$ & $\begin{array}{c}92.6 \\
9\end{array}$ & $\begin{array}{l}>90 \\
\text { national } \\
\text { standar } \\
\text { d }\end{array}$ & 0.1187 & 1.0299 \\
\hline & $\begin{array}{l}\text { Garbage } \\
\text { disposal rate }\end{array}$ & $\%$ & 100 & $\begin{array}{l}>90 \\
\text { national } \\
\text { standar } \\
\text { d }\end{array}$ & $\begin{array}{l}4.983 \\
e^{-16}\end{array}$ & 1.1111 \\
\hline & $\begin{array}{l}\text { GDP per } \\
\text { capita in ten } \\
\text { thousand }\end{array}$ & $\begin{array}{l}\text { ten } \\
\text { thousan } \\
\text { d }\end{array}$ & $\begin{array}{c}8021 \\
2\end{array}$ & $\begin{array}{l}>33000 \\
\text { national } \\
\text { standar }\end{array}$ & 0.0758 & 2.4307 \\
\hline
\end{tabular}




\begin{tabular}{|c|c|c|c|c|c|c|}
\hline & yuan & & & $\mathrm{d}$ & & \\
\hline & $\begin{array}{l}\text { Tertiary } \\
\text { industry } \\
\text { accounted }\end{array}$ & $\%$ & 42.1 & $\begin{array}{l}40 \\
\text { national } \\
\text { standar } \\
\text { d }\end{array}$ & 0.0658 & 1.0525 \\
\hline \multirow[t]{3}{*}{$\begin{array}{l}\text { Communi } \\
\text { ty }\end{array}$} & $\begin{array}{l}\text { Social urban } \\
\text { residents per } \\
\text { capita } \\
\text { disposable } \\
\text { income }\end{array}$ & yuan & $\begin{array}{c}4045 \\
4\end{array}$ & $\begin{array}{l}>24000 \\
\text { national } \\
\text { standar } \\
\text { d }\end{array}$ & 0.0673 & 1.6856 \\
\hline & $\begin{array}{lr}\begin{array}{l}\text { The } \\
\text { capita ner } \\
\text { income } \\
\text { rural }\end{array} \\
\text { households } \\
\end{array}$ & yuan & $\begin{array}{c}1961 \\
8\end{array}$ & $\begin{array}{l}>8000 \\
\text { national } \\
\text { standar } \\
\text { d }\end{array}$ & 0.0711 & 2.4523 \\
\hline & $\begin{array}{l}\text { The } \\
\text { registered } \\
\text { urban } \\
\text { unemployme } \\
\text { nt rate }\end{array}$ & $\%$ & 2.89 & $\begin{array}{l}<1.2 \\
\text { national } \\
\text { standar } \\
\text { d }\end{array}$ & 0.0844 & 0.4152 \\
\hline
\end{tabular}

Shaoxing City in 2013 for the evaluation of urban sustainable development capacity, with reference to Table 3 , and then come to thirteen indicators Euclidean distance is calculated from the following equation integrated: $\mathrm{d}=\sqrt[2]{\sum_{\mathrm{i}=1}^{13} \mathrm{~d}_{\mathrm{i}}}=0.3232$, and then come in Shaoxing City in 2013 sustainability assessment results.

\section{Evaluation of results}

For comparison, the evaluation on sustainable development in different regions, should be the appropriate level of pre-designed standard. Reference to the relevant research results at home and abroad, the design standard six levels to describe the extent of the sustainable development of the region[4], are shown in Table 4.

Table 4 Classification

\begin{tabular}{|c|l|l|}
\hline Grade & \multicolumn{1}{|c|}{ comprehensive distance value d } & \multicolumn{1}{|c|}{ basic features } \\
\hline 1 & $\mathrm{~d}<0.15$ & $\begin{array}{l}\text { High capacity for } \\
\text { sustainable development }\end{array}$ \\
\hline 2 & $0.15<\mathrm{d}<0.3$ & $\begin{array}{l}\text { High capacity for } \\
\text { sustainable development }\end{array}$ \\
\hline 3 & $0.3<\mathrm{d}<0.45$ & $\begin{array}{l}\text { Sustainable development in } \\
\text { general for }\end{array}$ \\
\hline 4 & $0.45<\mathrm{d}<0.6$ & $\begin{array}{l}\text { Poor capacity for } \\
\text { sustainable development }\end{array}$ \\
\hline 5 & $0.6<\mathrm{d}<0.75$ & $\begin{array}{l}\text { Poor capacity development } \\
\text { sustainable develope }\end{array}$ \\
\hline
\end{tabular}




\begin{tabular}{|c|l|l|}
\hline 6 & $\mathrm{~d}>0.75$ & $\begin{array}{l}\text { Worst capacity for } \\
\text { sustainable development }\end{array}$ \\
\hline
\end{tabular}

Comprehensive distance value from the table $6 \mathrm{~d}=0.3232$, Shaoxing City in the table 6 indicate that the sustainable development capacity is general grade three in 2013.

\section{Acknowledgement}

In this paper, the research was sponsored by the National Technology R\&D Program(2013BAJ04B04).

\section{References}

[1] solemnly China issues report on urban development [M] Beijing: China Development Press, 2004: 1-2.

[2]Lu Zhiqiangetc.Index of Sustainable of rural development Research ,HuaZhong Normal University( Nature science paper) 1998(2)

[3] [English] Ebenezer Howard tomorrow - Garden City [M] Jin Jing Yuan, translated Beijing: Commercial Press Press, 2000: 1-5.

[4] Song Yongchang, Qi Renhai, from Mansfield, and other indicators of the ecological system and the city's evaluation method [J] Urban Environment and Urban Ecology, 1999, 12 (5): 16-19.

Study

[5] Ma Shijun, Wang Rusong social - economic - natural complex ecosystem [J] Journal of Ecology, 1984, 4 (1): 1-9.

[6] SHEN Qingji urban ecology and urban environment [M] Shanghai: Tongji University Press, 1998: 3-11. 